\title{
Ĕ̆itim Fakültesi Öğretim Elemanlarının İletişim Becerileri: Öğretmen Adaylarının Perspektifinden Bir Değerlendirme Çalışması
}

\author{
Murat Bayram YILAR ${ }^{1}$, Yıldıray KARADAĞ² ve Mücahit AYDOĞMUŞ $\breve{S}^{3}$
}

\section{$\ddot{O} z$}

$\mathrm{Bu}$ araştırmanın amacı, eğitim fakültesinde görev yapan öğretim elemanlarının iletişim becerilerini öğretmen adaylarının bakış açısıyla değerlendirmektir. Araştırma, temel nitel araştırma desenine göre tasarlanmıştır. Araştırmanın katılımc1 grubunu, 2019-2020 eğitim-öğretim yllı bahar döneminde Türkiye'deki bir devlet üniversitesinin eğitim fakültesinde on üç farklı branşta öğrenim görmekte olan öğretmen adayları oluşturmaktadır. 61'i kadın, 17'si erkek olan katılımcıların belirlenmesinde iki aşamalı örneklem belirleme yoluna başvurulmuştur. Buna göre ilk aşamada ölçüt örnekleme ikinci aşamada ise maksimum çeşitlilik örneklemesi kullanılmıştır. Araştırmada veri toplama aracı olarak açık uçlu anket formu kullanılmıştır. Elde edilen veriler ise içerik analizi ile çözümlenmiştir. Araştırmada ulaşılan bulgular öğretim elemanlarının iletişim becerilerinin değerlendirilmesi ve öğretim elemanlarından beklentiler temaları altında toplanmıştır. Araştırma sonuçlarına göre öğretmen adayları, derslerine giren öğretim elemanlarının iletişim becerilerini ağırlıklı olarak olumsuz yönde değerlendirmişlerdir. Öğretim elemanlarının genel itibariyle iletişim sürecinde kılık-kıyafet seçimi ve Türkçeyi doğru kullanma konusunda olumlu; empati kurma, etkin dinleme, anlayışlı/hoşgörülü davranma, özsaygı geliştirici dil kullanma ve eleştiriye açık olma konusunda ise nispeten olumsuz değerlendirildikleri tespit edilmiştir.

Anabtar Kelimeler: İletişim, İletişim Becerileri, Öğretim Elemanları, Öğretmen Adayları, Eğitim Fakültesi

Communication Skills of Faculty of Education Instructors: An Evaluation Study from the Perspective of Teacher Candidates

\begin{abstract}
The aim of the study is to evaluate the communication skills of academic staff working in the education faculty from the perspective of teacher candidates. The research was designed according to the basic qualitative research design. The teacher candidates that are educating in thirteen different branches in the faculty of education at a state university in Turkey during spring semester of 2019-2020 academic years form the participants of research. In determining the participants which are 61 women and 17 men, two-stage sampling method was used. Accordingly, criterion sampling was used in the first stage and maximum diversity sampling was used in the second stage. In the study, an open-ended questionnaire form was used as a data collection tool. The obtained data were analyzed by content analysis. According to the results obtained from the study, teacher candidates evaluated the communication skills of the teaching staff negatively. It was determined that the instructors are generally evaluated positively about the choice of attire and the correct use of Turkish in the communication process; whereas they were evaluated relatively negatively in terms of empathy, active listening, understanding / tolerant behavior, using self-esteem enhancing language and being open to criticism.
\end{abstract}

Key Words: Communication, Communication Skills, Instructors, Teacher Candidates, Faculty of Education

\section{Atıf İçin / Please Cite As:}

Yılar, M. B., Karadağ, Y. ve Aydoğmuş, M. (2021). Eğitim fakültesi öğretim elemanlarının iletişim becerileri: öğretmen adaylarının perspektifinden bir değerlendirme çalışması. Manas Sosyal Araştırmalar Dergisi, 10(4), 2160-2175.

Geliş Tarihi / Received Date: 10.01.2021

Kabul Tarihi / Accepted Date: 01.04.2021

\footnotetext{
${ }^{1}$ Dr. Öğr. Üyesi - Ondokuz Mayıs Üniversitesi Eğitim Fakültesi, bayram.yilar@omu.edu.tr

ORCID: 0000-0001-5889-3372

2 Arş. Gör. - Ondokuz Mayıs Üniversitesi Eğitim Fakültesi, yildiray.karadag@omu.edu.tr

ORCID: 0000-0002-0336-7815

3 Arş. Gör. - Ondokuz Mayıs Üniversitesi Eğitim Fakültesi, mücahit.aydogmus@omu.edu.tr

(i) ORCID: 0000-0002-1418-1100
} 


\section{Giriş}

İnsan, var oluşu gereği doğa ve çevreyle, diğer insanlarla ve kendi iç dünyasıyla sürekli bir etkileşim içerisinde hayatını devam ettirmektedir. Toplumsal bir varlık olma yönü göz önüne alındığında insanın diğer insanlarla olan etkileşiminin en önemli boyutunu iletişim oluşturmaktadır. İletişim sürecinin temelinde anlamak ve anlaşılmak yatmaktadır (Tuna, 2014, s. 6). İletişim; bilginin çeşitli yollarla iletildiği ve alındığı sözlü ve sözsüz bilgi alışverişi (Barker, 1999, s. 89) ile insanlar arasındaki bilgi paylaşımı (Gilligan vd., 2018, s. 3618) olarak tanımlanmaktadır. Bu tanımlardan da anlaşılacağı üzere iletişim, insanın hayatını devam ettirebilmesi, problemlerini çözüme kavuşturabilmesi kısacası çevreye uyum sağlayabilmesi için gerekli olan önemli bir kavram olarak karşımıza çıkmaktadır (Akgün ve Çetin, 2018, s. 104; Koç Akran, Acıdemir ve Uludağ, 2018, s. 70). Çünkü kişiler arası ilişkilerin kurulmasında ve geliştirilmesinde iletişimin rolü büyüktür. İletişim temelde diğer insanları anlamak, özümsemek ve tepki vermektir (Özer, 2011, s. 20). İletişim becerisi ise sözel ve sözel olmayan iletilere duyarlı olma, etkili dinleme ve tepki vermeyi ifade etmektedir (Erözkan, 2007, s. 60). Aynı zamanda iletişim becerisi karşılaşılan olaylarla ilgili bakış açılarını genişletmek, farklı yorum ve seçenekler arasından hangilerini kullanarak çözüme ulaşılabileceğini bilmek olarak ifade edilmektedir (Akyol, 2019, s. 72). İletişim becerilerinin etkililiği insan ilişkilerinde ve meslekî ilişskilerde kolaylaştırıcı olabilmektedir (Akgün ve Çetin, 2018, s. 104). Dolayısıyla iletişim sürecinin başarılı olabilmesi için insanların etkili iletişim becerilerine sahip olması gerektiği ifade edilebilir.

Yoğun bir şekilde insanlarla iletişimi gerekli kılan mesleklerde, iletişimin önemi bir kat daha artmaktadır. Bu tür mesleklerde, mesleğin gereğini yerine getirirken iletişim becerilerini etkili kullanmak meslekî başarıda kilit rol oynamaktadır. Ögretmenlik de bu meslek dallarından biridir. Öğretmenlerin eğitim-öğretim süreçlerinde iletişim becerilerini etkili kullanmaları eğitim öğretimin niteliğini, öğrenci başarısını ve ilgisini olumlu yönde etkileyebilmektedir (Uzun, Özdem ve Kara, 2018, s. 625; Zlatic, Bjekic, Marinkovic ve Bojovic, 2014, s. 606). Çünkü öğrenme süreci aynı zamanda bir iletişim ve etkileşim sürecidir (Baykara Pehlivan, 2005, s. 17). Öğretim hedeflerine başarılı bir şekilde ulaşılabilmesi için iletişim süreçlerinin etkili olması gerekmektedir. Buradan hareketle öğretmenliğin bir iletişim mesleği olduğu ve etkili iletişim becerilerine sahip olmanın da önemli bir meslekî yeterlik olduğu söylenebilir (Dilekman, Başç1 ve Bektaş, 2008, s. 223). Eğitim-öğretim ortamı içerisinde iletişimin temel öğeleri öğretmen, öğrenci, yönetici ve velilerdir. Bu öğeler arasındaki iletişim süreçleri şüphesiz çok önemlidir. Özellikle öğretmen ve öğrenciler arasındaki iletişim, eğitim yaşantılarını diğerlerine göre daha fazla etkilemektedir. Çünkü öğrenme etkinliklerinde iletişim sürecinin başlatıcısı ve düzenleyicisi bir kaynak olarak öğretmendir (Çetinkaya, 2011, s. 568). Öğretmen ve öğrenciler arasındaki iletişimin sağlıklı olmadığı durumlarda diğer öğeler arasındaki iletişim süreçleri de olumsuz etkilenmektedir. Ayrıca eğitim-öğretim etkinliklerinin büyük bir çoğunluğunun sınıf içerisinde ve yalnızca öğretmen ve öğrencilerin bulunduğu bir ortamda gerçekleşiyor olması da öğretmen-öğrenci iletişiminin ne kadar önemli olduğunu ortaya koymaktadır (Korkmaz, 2007, s. 69). Öğretmenlerden, öğrencilerin beklentilerine uygun bir iletişim kurmas1 beklenmektedir. Çünkü öğretmen ve öğrenci arasındaki iletişim, öğrencilere yeni tutum ve davranışların kazandırılmasında (Tomul, 2015, s. 147), öğrencilerin duyuşsal ve bilişsel öğrenmeleri üzerinde (LeFebvre, ve Allen, 2014, s. 38), öğrencilerin öğrenme ve ders tatmininde (Arbaugh, 2001, s. 49) önemli bir rol oynamaktadır. Bunların yanı sıra iletişim ile örgütsel bağlılık, iş tatmini, sınıf yönetimi becerileri, sosyal medya bağımlılı̆̆ı, sorgulama becerileri, öğretim becerileri, olumlu bir sınıf ortamı oluşturulması, sosyal beceri ve ilişkiler, problem çözme becerileri, motivasyon, duygusal zekâ, empati eğilimi ve becerisi arasında ilişkiler olduğu yapılan bazı çalışmalarda ortaya konulmuştur (Aküzüm ve Özdemir Gültekin, 2017; Aliusta, Akmanlar ve Gökkaya, 2019; Bakır, 2019; Baydar Posluoğlu, 2014; Çakır ve Ünal, 2019; Erözkan, 2013; Gürşimşek, Vural ve Selçioğlu Demirsöz, 2008; Mart, 2014; Nacar, 2010; Nacar ve Tümkaya, 2011; Tepeli ve Arr, 2010; Yavuzer, 2001; Yılmaz, Yoncalık ve Çimen, 2010; Yüksel, 2005). Bütün bu çalışmalar iletişim olgusunun öğrenme sürecini çeşitli şekillerde etkilediğini göstermekte ve dolayısıyla, öğretmenlerin iletişim becerilerinin geliştirilmesinin kaçınılmaz bir zorunluluk olduğu ortaya çımaktadır.

Öğretmenlik Mesleği Genel Yeterlikleri’nde, 21. yüzyıl becerileri arasında sayılan etkili iletişim becerisini kazanmış nesillerin yetiştirilmesinin amaçlandığına ve öğretmenlerin güçlü bir iletişim becerisine sahip olması gerektiğine vurgu yapılmaktadır. Böylece iletişim ve iş birliği becerisi en önemli yeterlik alanları arasında belirtilmektedir (Millî Eğitim Bakanlığ1 [MEB], 2017, s. 16). Ayrıca iletişim ve iş birliği yeterlik alanı ile ilgili yeterlik göstergeleri "Türkseyi kurallarnna uygun ve etkili biçimde kullanma, etkili iletişim yöntem ve tekniklerini kullanmaya özen gösterme, insan ilişkilerinde empati ve hosgörüyü esas alma" şeklinde ifade edilmektedir (MEB, 2017, s. 16). Öğretmenlerin iletişim becerilerinin geliştirilmesine yönelik hizmet içi dönemlerde yapılan çalışmalar çoğunlukla seminer, kurs vb. eğitim etkinlikleriyle sürdürülmektedir. Hizmet 
öncesi dönemde ise öğretmen adaylarının etkili iletişim kurabilen öğretmenler olarak yetişmeleri için öğretmenlik lisans programlarında genel kültür seçmeli dersleri kapsamında iletişim becerilerini geliştirmeye yönelik "İnsan İlişkileri ve İletişim" dersi yer almaktadır (Yükseköğretim Kurulu [YÖK], 2018, s. 19). Bununla birlikte ögretmen adaylarına etkili iletişim becerilerinin kazandırılmasında öğretim elemanlarının rol model olması da önem arz etmektedir. Çünkü iletişim süreci sözel ve bedensel unsurları ile muhatabı izlemeyi, dinlemeyi ve tepki vermeyi içermektedir. Tüm öğrenciler gibi öğretmen adayları da ögretmenlerinin dili kullanma biçimlerini, telaffuz ve hitabet yeteneklerini, jest, mimik ve tüm beden dili kullanım tarzlarını izlemektedirler. Öğretmenlerini izleyerek ve dinleyerek tecrübe ettikleri davranışlar ise onların iletişim süreçlerindeki davranışlarını şekillendirmektedir. $\mathrm{Bu}$ nedenle okul öncesinden yükseköğretime kadar tüm düzeylerde öğretmenlerin öğrencilerine örnek teşkil edecek iletişim deneyimleri yaşatmalarının etkili olabileceği düşünülmektedir. Özellikle de öğretmen yetiştiren kurumlar olan eğitim fakültelerinde görev yapan öğretim elemanlarının sahip oldukları iletişim becerileri, gelecek nesilleri yetiştirecek olan öğretmen adaylarının etkili iletişim kurabilen öğretmenler olarak yetişmelerinde önemli görülmektedir. Literatürde öğretmenlerin iletişim becerilerinin incelendiği çeşitli araştırmalar olduğu görülmektedir (Aslan Bağc1 ve Efilti, 2019; Baydar Posluoğlu, 2014; Bozkurt Bulut, 2004; Derici Cevap, 2017; Durukan ve Maden, 2010; Kadığlu Ateş ve Bulut, 2019; Kayhan, 2014; Kılıç, 2013; Küpeli, 2019; Nacar ve Tümkaya, 2011; Şimşek ve Bakır, 2019; Uzun, Özdem ve Kara, 2018; Yılmaz, 2011). Ancak öğretim elemanlarının, özellikle de öğretmen yetiştiren kurumlarda görev yapan öğretim elemanlarının iletişim becerilerinin incelendiği herhangi bir araştırmaya rastlanmamış olmasının bu araştırmanın ortaya çımasında etkili olduğu söylenebilir. Dolayısıyla öğretim elemanlarının iletişim becerilerinin nitel bir yaklaşımla, derinlemesine, öğretmen adaylarının bakış açılarıyla incelenmesinin önemli olduğu düşünülmektedir. Araştırma sonuçlarının eğitim fakültelerinde görev yapan öğretim elemanları başta olmak üzere tüm öğretmen ve eğitimcilere önemli dönütler sağlayacağı beklenmektedir. Buradan hareketle bu araştırma eğitim fakültesinde görev yapan öğretim elemanlarının iletişim becerilerini öğretmen adaylarının bakış açısıyla değerlendirmeyi amaçlamaktadır. Bu amaç doğrultusunda araştırmada başlıca şu sorulara cevap aranmaktadır:

- Öğretmen adaylarının, öğretim elemanlarının iletişim becerilerine yönelik deneyimleri nelerdir?

- Öğretmen adaylarının, öğretim elemanlarından iletişim ile ilgili beklentileri nelerdir?

\section{Yöntem}

\section{Desen}

Araştırmada eğitim alanında sıklıkla tercih edilen ve nitel araştırma desenlerinden biri olan temel nitel araştırma kullanılmıştır. Temel nitel araştırma, bireylerin bir olay ve olguya yönelik görüşlerini yorumlayıc1 bir biçimde sunmak ve deneyimlerine ne anlam kattığın belirlemek için tercih edilen bir nitel araştırma desenidir (Merriam ve Tisdell, 2016, s. 24). Bu desenin tercih edildiği araştırmalarda, katıllımclara yöneltilen sorular, gözlemlenecek olgu ve incelenecek dokümanlar araştırmanın teorik çerçevesine bağlı olarak belirlenir. Veriler ise görüşmeler, gözlemler veya doküman analizi yoluyla toplanabilir (Merriam ve Tisdell, 2016, s. 24). Bu kapsamda araştırmada öğretmen adaylarının derslerine giren öğretim elemanlarının iletişim becerilerine yönelik deneyimlerini, beklentilerini ve kendilerinde geliştirmek istedikleri becerileri ortaya koymak için bu desenin kullanılması uygun bulunmuştur.

\section{Katılımc1 Grubu}

Araştırmanın katılımcı grubunu, 2019-2020 eğitim-öğretim yllı bahar döneminde Türkiye'deki bir devlet üniversitesinin eğitim fakültesinde çeşitli branşlarda öğrenim görmekte olan öğretmen adayları oluşturmaktadır. Katılımcıların belirlenmesinde iki aşamalı örneklem belirleme yoluna gidilmiştir. İlk aşamada ölçüt örnekleme yöntemi kullanılmışır. Ölçüt örnekleme araştırma öncesinde belirlenmiş bir dizi ölçüte sahip olan durumları veya bireyleri çalsşmaya dâhil etmeyi ifade etmektedir (Patton, 2014, s. 238). Bu doğrultuda araştırmanın ölçütü "İnsan İlişkileri ve İletişim dersini başarılyla geçmek" şeklinde belirlenmiştir. Bu ölçütün tercih edilmesindeki amaç, öğretmen adaylarının öğretim elemanlarının iletişim becerilerine ilişkin deneyimleri, beklentileri ve kendilerinde geliştirmek istediği becerilere yönelik görüşleri daha nesnel ve doğru bir biçimde ortaya koyabilme kaygısıdır. İkinci aşamada ise maksimum çeşitlilik örneklemesi kullanılmışır. Maksimum çeşitlilik örneklemesi çalışmanın amacına bağlı olarak bilgi açısından zengin durumların seçilerek derinlemesine araştırma yapılmasına olanak sağlayan bir yöntemdir (Patton, 2014, s. 238). Bu kapsamda araştırmaya eğitim fakültesinde Almanca Öğretmenliği, Biyoloji Öğretmenliği, Fen Bilgisi Öğretmenliği, Fransızca Öğretmenliği, İngilizce Öğretmenliği, İlköğretim Matematik Öğretmenliği, Müzik Öğretmenliği, Okul Öncesi Öğretmenliği, Rehberlik ve Psikolojik Danışmanlık 
Öğretmenliği, Resim Öğretmenliği, Sınıf Öğretmenliği, Sosyal Bilgiler Öğretmenliği ve Türkçe Öğretmenliği bölümlerinde öğrenim görmekte olan 78 öğretmen adayı dâhil edilmiştir. Nitel araştırmalarda daha küçük katılımcı gruplar ile çalışmak nispeten yaygın olsa da Lincoln ve Guba (1985, s. 202) tarafindan katılımcı grup büyüklüğünün, doygunluk ve aşırllık seviyesine ulaşıncaya kadar seçilebileceğini ifade etmektedir. Nitekim bu araştırmada da katılımcı grubunun büyüklügü bu ilkeler göz önüne alınarak belirlenmiştir. Araştırmaya dâhil edilen katılımcıların 61'i kadın, 17'si erkektir.

\section{Veri Toplama Arac1}

Araştırmanın verileri araştırmacılar tarafından geliştirilen yapılandırılmış görüşme formu aracilı̆̆ıla elde edilmiştir. Yapılandırılmış görüşme formları; görüşülen kişilerin verdikleri cevaplar arasındaki benzerlikleri ve farklılıkları belirlemek ve karşılaştırmalar yapmak için kullanılan veri toplama araçlarıdır (Brannigan, 1985 Akt: Yıldırım ve Şimşek, 2016, s. 130). Formun geliştirilme sürecinde ilgili alan yazında iletişim becerilerine yönelik farklı araştırma yöntemleriyle yürütülen araştırmalar incelenmiş ve kullanılan veri toplama araçları dikkate alınmıştır. Formun geliştirilme sürecinde öncelikle 6 farklı soru tipi hazırlanmış daha sonra bu sorular nitel araştırma alanında uzman iki öğretim üyesi tarafından incelenmiştir. İnceleme sonucunda 2 kapsamlı açık uçlu soru üzerinde nihaî karar verilmiştir. Birinci soru "Eğitim fakültesinde derslerinize giren öğretim elemanlarmın iletişim becerilerine yönelik deneyimleriniz nelerdir?" şeklinde belirlenmiştir. Bu soru kapsamında öğretmen adaylarından öğretim elemanlarının hangi iletişsim becerilerini kullanmada yeterli ya da yetersiz olduklarını gerekçelendirerek açıklamaları istenmiştir. İkinci soru ise "Ë̈itim fakültesinde derslerinize giren ögretim elemanlarndan iletişim konusundaki beklentileriniz nelerdir?" şeklinde hazırlanmıştır. Oluşturulan açı uçlu sorular katıllımcılara sunulmadan önce 7 öğretmen adayı ile ön deneme yapılmış ve elde edilen veriler araştırma kapsamı dışında tutulmuştur.

\section{Verilerin Analizi}

Verilerin analizinde ise içerik analizi yaklaşımı benimsenmiştir. İçerik analizi geniş olan nitel materyali alarak temel tutarlıkları ve anlamları belirlemeye yönelik nitel veriyi azaltma ve indirgeme çabasıdır (Patton, 2014, s. 453). Bu kapsamda toplanan veriler önce kavramsallaştırılır sonra ise ortaya çıkan kavramlara göre mantıklı bir biçimde düzenlenir ve veriyi açıklayan temalar saptanır (Yıldırım ve Şimşek, 2016, s. 242). Bu araştırmada da içerik analizi yaklaşımı benimsenerek elde edilen veriler kavramsallaştırılmış, düzenlenmiş ve kod, kategori ve temalar belirlenmiştir. Ardından öğretmen adaylarının öğretim elemanlarının iletişim becerilerine yönelik deneyimlerine ve beklentilerine ilisskin bilgiler sayısallaştırllarak sunulmuştur.

\section{Bulgular}

Araştırmanın bu bölümünde, katılımcıların öğretim elemanlarının iletişim becerilerine yönelik deneyimlerinden elde edilen verilerin analizi neticesinde ortaya çıan bulgulara yer verilmiştir. $\mathrm{Bu}$ doğrultuda öğretmen adaylarının verdikleri cevaplardan yola çıkılarak veriler 2 tema etrafinda biçimlenmiştir. Birinci tema, ögretim elemanlarının iletişim becerilerinin değerlendirilmesi ve ikinci tema ise iletişim konusunda öğretim elamanlarından beklentilerdir.

\section{Öğretim Elemanlarının İletişim Becerilerinin Değerlendirilmesi}

Araştırmada elde edilen bulgulara göre katılımcıların, öğretim elemanlarının iletişim becerilerini değerlendirmelerine yönelik olumlu ve olumsuz görüşleri en sık tekrar edilen iletişim becerisinden en az tekrar edilen iletişim becerisine doğru sayısallaştırilarak Tablo 1'de sunulmuştur. 
Tablo 1. Öğretim Elemanlarmm İletişim Becerileri

\begin{tabular}{lccc}
\hline Beceriler & Olumlu & Olumsuz & Toplam \\
\hline Empati kurma & 10 & 33 & 43 \\
Kilık-kyafet & 32 & 6 & 38 \\
Türkçeyi etkili kullanma & 30 & 7 & 37 \\
Özsaygı geliştirici dil kullanma & 13 & 18 & 31 \\
Anlayışlı ve hoşgörülü davranma & 12 & 18 & 30 \\
Etkin dinleme & 9 & 21 & 30 \\
Saygllılma & 16 & 12 & 28 \\
Beden dilini etkili kullanma & 8 & 10 & 18 \\
Önyargıdan uzak olma & 8 & 9 & 17 \\
Ben dilini kullanma & 7 & 7 & 14 \\
Eşit yaklaşabilme & 3 & 5 & 8 \\
Somut, açı ve anlaşllır konuşma & 3 & 5 & 8 \\
Uygun göz teması kurma & 6 & 2 & 7 \\
Hitabet & 3 & 4 & 5 \\
Eleștiriye açı̈k olma & 1 & 4 & 5 \\
Sözel ve sözel olmayan davranışları uyumlu kullanma & 4 & 1 & $\mathbf{3 2 7}$ \\
\hline Toplam & $\mathbf{1 6 5}$ & $\mathbf{1 6 2}$ & \\
\hline
\end{tabular}

Tablo 1 incelendiğinde katılımcıların, öğretim elemanlarının iletişim becerilerini değerlendirmelerinde en çok empati, kılık kıyafet, Türkçeyi etkili kullanma, özsaygı geliştirici/zedeleyici dil kullanma, anlayışlı ve hoşgörülü davranma, etkin dinleme gibi becerilere odaklandıkları belirlenmiştir. Bu becerilerin yanında katılımcılar saygı duyma, beden dilini etkili kullanma, önyargilardan uzak olma, ben diliyle konuşma gibi becerileri de sıklıkla değerlendirmiştir. Bu doğrultuda öğretmen adayları tarafından en sık tekrar edilen ve öğretim elemanlarının en fazla olumsuz değerlendirilen iletişim becerisi empati kurma olmuştur. Katılımcıların çoğunluğu, öğretim elemanlarının hem uzaktan öğretim sürecinde hem de yüz yüze eğitim sürecinde ders akışı, materyal temin etme, sınav kapsamı veya gündelik problemler gibi konularda empati kurmadıklarını ve dolayısıyla kendilerini anlamadıklarını dile getirmişlerdir. Örneğin katılımcılardan K18“... hocalarmm々 pandemi sürecinde vize ödevleri veya smavlar, evimizdeki internet veya bilgisayar olanaklarmin uygunluğn gibi konularda empati yapmyyorlar. Gülerek, gerekirse belediyelere gitmemiz gerektig̈ini, onlarn evlerinde 3'er tane laptop olduğunu söylïyorlar" cümleleri ile öğretim elemanlarının Covid-19 sürecinde gerçekleştirilen uzaktan öğretim sürecinde empati kurmadıklarını ve dolayısıyla öğrencileri anlamadıklarını ifade etmiştir. Katılımcilardan K70 ise "... derslerle ilgili baz̨ sı kintılar olduğunda klasik şu cevaplar alyorum; kocaman adam oldunuz, üniversite ögrencisi oldunuz, bunu yapmak siz̨in sorumluğunuzda vb. Baz? sorumluluklar almamız? istiyor olabilirler ancak imkânlarn kısıtlı olduğunu ya da her ögrencinin ayn imkânlara sahip olmadĭğm anlamiyorlar." cümleleri ile öğretim elemanlarının öğrencileriyle empati kuramadıklarını dile getirmiştir. Katılımcıların en sık tekrar ettiği ve öğretim elemanlarını iletişim konusunda en olumlu gördüğü beceri ise killk-kıyafete dikkat etme ve dış görünüşe önem vermedir. Katılımciların büyük çoğunluğu öğretim elemanlarının okula veya derslere gelirken uygun kıyafetleri tercih ettiğini, şı olduğunu, kıyafetlerinin olumsuz mesajlar vermediğini dile getirmişlerdir. Kllk-kıyafete dikkat etme ve önem verme becerisi hakkında sadece 5 katılımcı olumsuz görüş bildirmiştir. Katılımcıların olumlu ve olumsuz düşüncelerine yönelik bazı görüşleri şöyledir;

K35: "Hocalarmm々 kullk kiyafet konusunda dikkeatliler. Bir eğitimciye yakışır șekilde givinmeye dikekat ediyorlar. Bu da ögrencilerin onlara olan saygısın artırp iletisimi güglendiriyor."

K40: "Her hocam diş görünüse dikekat ediyor, uygun kiyafet giviyor. Mesela bir hocam her derse takım elbise ise geliyor...."

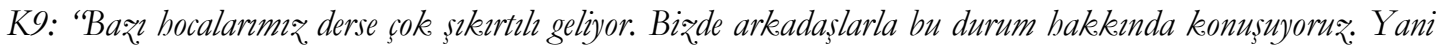

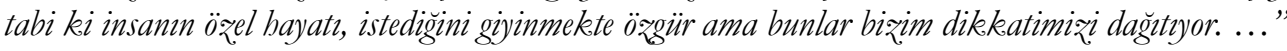

K57: "Genel bir değerlendirme yapacak olursam kullk keyafete pek önem vermiyorlar. Akademik statü itibari ile bizden üstün olan hocalarmmırn sinfta ayurt edici olması lazım. Kullke keryafet açısndan ayurt edici olmayan hocalarmı ögrenciler üzerinde sağglkli iletişim kuramyyorlar."

K11: "Dış görünüs ve derse uygun kiyafetle gelme açsından değerlendirdiğim de bir hocamį bic unutmuyorum. Hocamiz derse essofman ile gelmişti ve 8.15 dersiydi, çok erken bir saat ama yine de yadirgamuștum. Hocalarmı̨̊n da açıkçası yürüyüse gidiyormus gibi gelmesi bana çok doğru gelmiyor. Sonuçta resmi bir kuruma geliyoruz hem derse hem ögrenciye saygrmızdan ayn zaman da kendimize saygumızdan ötürü ben kullk kiyafetimize dikekat etmemiz gerektigini düsünüyorum." 
Katıllımcıların en sık tekrar ettiği ve öğretim elemanlarını iletişim konusunda en olumlu gördügü bir diğer beceri Türkçeyi etkili kullanmadır. Katılımcılar genel olarak öğretim elemanlarının Türkçeyi etkili ve anlaşılır bir biçimde kullandıklarını, diksiyonlarının iyi olduğunu dile getirmişlerdir. K77’nin bu konuda

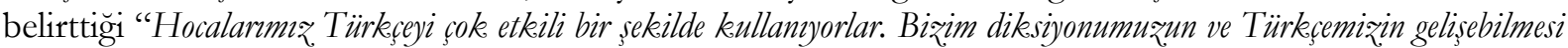

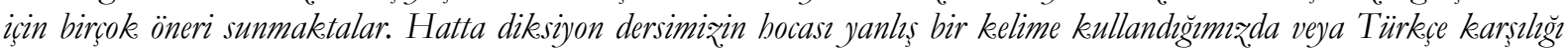

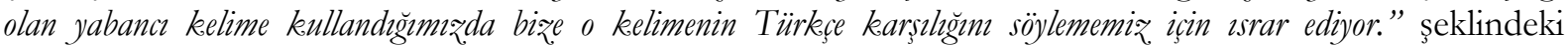
düşünceleri dikkat çekicidir. Katıllımclların bu konudaki olumsuz düşüncelerinin temelinde ise öğretim elemanlarının hızlı ve karmaşı konuşması, ses tonunu ayarlayamaması, akıcı konuşamaması, aynı kelime veya cümleleri sıklıkla tekrar etmesi ve cümleler arasında uzun süreli duraksamaları gibi iletişim engelleri yer almaktadır. Katılımcılardan K17 "Geşen ynlki matematik dersi hocamız çok brğl konuşurdu ne dediğini

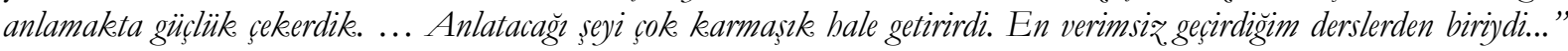
cümleleri ile hızlı ve karmaşık konuşmanın iletişimde olumsuz yönüne; K20 “... ses tonunu iyi kullanamayan hocalarm coğunlukta. İlk iki sura hariç hocalarn sesi diğer yerlere ulaşmyor." cümleleri ile ses tonunun iletişimdeki engeline ve K72 de "bą? hocalar konusurken ayn kelimeleri sürekli tekrar edip sanki tüm ders boyunca aym konuyu anlatiyormus gibi oluyor. Bažen ise ne diyeceğine karar veremeyip ya da başka bir nedenden ötürü konuşma sirasinda sürekli duraksyyor. Bu durumda ise derse olan ilgi kayboluyor." cümleleri ile kelime tekrarının ve uzun süreli duraksamaların derse yönelik ilgiyi kaybettirdiğine vurgu yapmışlardır.

Katıllımcıların en sık tekrar ettiği ve öğretim elemanlarının iletişim konusunda nispeten olumsuz olarak nitelendirdiği bir diğer beceri özsaygı geliştirici dil kullanımıdır. Katılımcılar, öğretim elemanlarının iletişim becerilerini değerlendirirken özsaygı geliştirici/zedeleyici dil kullanımına toplam 31 defa vurgu yapmışlardır. Buna göre katılımcıların 13’ü öğretim elemanlarının özsaygı geliştirici dil kullandıklarını; 18’i ise özsaygı zedeleyici dil kullanarak kendileriyle iletişim kurduklarını ifade etmiştir. Özsayg1 zedeleyici dil kullanımı konusunda hakaret etme, üslûba dikkat etmeme, küçümseme/hor görme, aşağılama, sürekli olumsuz eleştiri, suçlayıcı tavır gibi olumsuz iletişim unsurlarına değinilmiştir. Özsaygı geliştirici dil kullanımına yönelik deneyimleri olduğunu da ifade eden öğrenciler ise öğretim elemanlarının genel olarak kendilerine hakaret etmediklerini, kıııı olmadıklarını, cümlelerini ve hareketlerini özenle seçtiklerini ve üslûplarının iyi olduğunu dile getirmişlerdir. Katılımcıların, öğretim elemanlarının iletişimde özsaygı geliştirici ya da özsaygı zedeleyici dil kullanımına yönelik deneyimlerine ilişkin ifadelerinden bazıları şöyledir;

K15: "Bir konu hakkenda söz hakker alarak konusulurken kendi fikrimi dile getirdigimde hocamdan sert ve

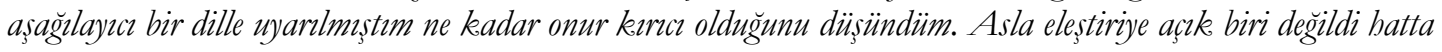
bana güzel bir dille hakaret edercesine konuşmustu."

K29: "Örnek vermek gerekirse kimya laboratwvar dersinden çok fąla sikentı çektik. Hoca yapulacak bir deneyin sadece ismini söylïyordu ve bizden teblikeli bile olsa o düzeneği kurup deneyimizi yapmamız̨ istiyordu. Yardim istediğimizde ise işitmediğimiz bakaret kalmiyordu."

K61: "... Baz̨ hocalarmm tam tersi asla ögrenciye sayg duymayan bir üslupla hep ögrenciyi yeren hep ögrenciyi aşağrlayan tavirlaryla iletişimi sifira indiriyorlar. Bu tip hocalarmm genelde bize hep asla başaramayacağrz seylerden bahsediyorlar ve bep en zayrfyönlerimizi görïp bizim bir birey olarak kendimizi değersiz hissetmemize sebep oluyorlar. Pesimist düş̈̈nceleri ve ögrenciyi aşağg gören tavirlar da var olan iletisimi etkisiz hale getiriyor."

K2: "Hocalarmı güler yüzlï, dikekat edilmesi gereken yerlerde bizlleri uyarabiliyorlar. Bizlerle bakaret içerikli

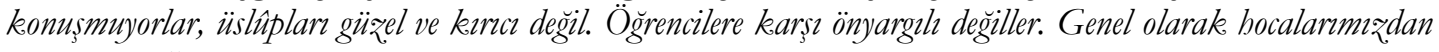
memnunum."

K32: "Hakaret boyutunda bir olay yasamadom ve yasayabileceğimi düs̈̈̈nmüyorum bölüm bocalarm kurduğu cümleleri kesinlikle dürgün seçebilen insanlardr."

K33: "Bir eğitimcinin tavr çok önemlidir. Öğrencilerle konuşmasi, genel durusu, bareketleri yani her şeyi çok önemlidir. Bunlar ögrencilerin dikkati çok çekizor. Örnek vermem gerekirse dersimize giren bir ögretmenin

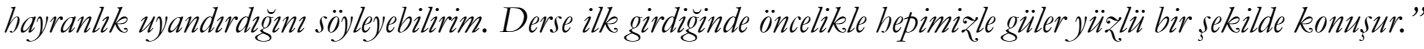

Katılımcıların öğretim elemanlarının özsaygı geliştirici/zedeleyici dil kullanımı konusundaki deneyimlerinin farklılaşmasının temel sebeplerinden biri hem öğrenim gördükleri sınıf seviyesi hem de öğrenim gördükleri bölümlerin farklılık göstermesidir. Dolayısıyla derslerine giren öğretim elemanları çoğunlukla farklıdır. Yine öğrencilerden soruları objektif bir biçimde yanıtlamaları istenmiş olsa da kaçınılmaz olarak aynı sınıfta aynı ögretim elemanından ders alan iki ayrı öğrencinin yorumu dahi farklılık gösterebilmektedir. Nitekim olumlu deneyimlere sahip olduğunu ifade eden öğrencilerin sayıları bütün 
bölümler içinde nispeten birbirine yakın dağılırken, olumsuz düşünceye sahip olan öğrencilerin ise çoğunlukla Fen Bilgisi Öğretmenliği ve İngilizce Öğretmenliği bölümlerinde toplandığı görülmektedir. Ayrıca bu durumun bir diğer sebebinin öğrencilerin aldıkları seçmeli derslere göre de değişebileceği düşünülmektedir.

Katılımcıların en sık tekrar ettiği ve çoğunlukla olumsuz deneyimlere sahip olduğu diğer iletişim becerileri anlayışlı ve hoşgörülü davranma ile etkin dinlemedir. Katılımcılar, öğretim elemanlarının karşılaştıkları sorunlara anlayışla yaklaşmadığını, hoşgörü göstermediğini hatta çoğu zaman onları etkin bir biçimde dinlemediklerini dile getirmişlerdir. Katılımcılardan K41 anlayışlı olma ve hoşgörülü davranma

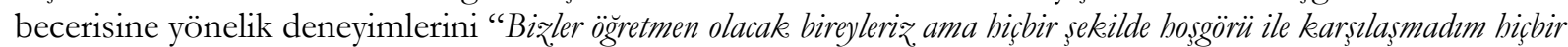
hocamdan. Anlayışla yaklașma da ayn şekilde, birilerinin biə̨i anlamaya çalıs̆tiğna şahit olmadim." cümleleri ile ifade etmiştir. K12 "karantina süresince her hoca kendi dersini baz alarak hem birçok ödev veriyorlar hem de bu ödev sürelerini

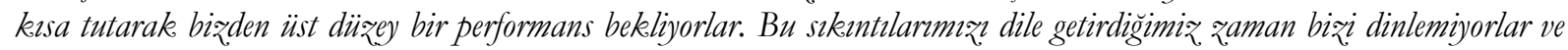
anlayışla karşılayamyyorlar." şeklindeki cümleleriyle anlayışlı ve hoşgörülü davranma ile etkin dinleme becerisine yönelik deneyimlerinde uzaktan eğitim sürecine vurgu yapmıştır. Katılımcıların sık tekrar ettiği ve çoğunlukla olumlu deneyimlere sahip olduğu bir diğer beceri ise saygılı olmadır. Katılımcıların bu düşüncelerinin temelinde ise öğretim elemanlarının öğrencilerine ilgi göstermesi, değer vermesi, aşağılayıc1 söz ve hareketlerden kaçınması, öğrencinin görüşlerini dinlemesi, olumlu ve çözüm odaklı bireyler olması gibi diğer birçok iletişim becerisinin etkin bir biçimde kullanılması yatmaktadır. Nitekim K56'nın şu cümleleri bu bulguları destekler niteliktedir;

"Ögrrencilerine ve işine sayg duyan kişiler olduklarm düşünüyorum. Bu düsüncemin nedeni ise olumlu ve çöఇüm odakl y yaklasımlarn, derslerde göz teması kurarak, uygun killk kiyafet tercih ederek, ögrencilerin görüslerine önem

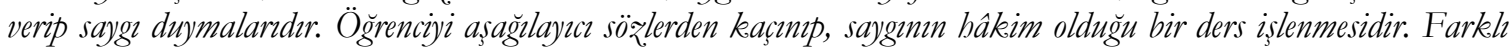
görïslere karşı coğnnlukla sayge duyulması da bir diğer olumlu yandir."

Katılımcilardan bazıları ise saygılı olma becerisine yönelik olumsuz deneyimlere sahip olduklarını dile getirmişlerdir. Bu deneyimlerde karşılaşılan sorunlar genelde öğrenci görüşlerini dikkate almama, etkin dinlememe, öğrenciye lâkap veya isim takma, küçük düşürücü söylemler, derse verimli ve etkili hazırlanmama ve geç gelme gibi konular üzerinde yoğunlaşmaktadır. Örneğin K34 “... Sürekli derse geç gelen bana saygisi olmayan ögrretim üyeleri var ve bu aramızdaki iletişimi olumsuz etkiliyor." ve K39 "Ögrrenciye olan saygzmn göz ard edildig̈̈ni söyleyebilirim. Buna örnek olarak, hocann odasma gelen ögrenciyi dinlemeyip bassndan savan bareketleriyle ögrencinin odasından cıkmasin isteyecek davranıslarda bulunup ögrenciyle kötü bir iletisism kurduğunu söyleyebilirim." şeklindeki ifadeleri ile iletişimde saygılı olma konusunda öğretim elemanları ile yaşadıkları deneyimleri ifade etmişlerdir.

Katılımcılar tarafindan öğretim elemanlarının iletişim becerilerine yönelik diğer deneyimleri incelendiğinde hitabet, önyargilı olmama ve eşit yaklaşabilme becerilerinin genel olarak olumsuz değerlendirildiği anlaşılmaktadır. Ulaşılan bulgulara göre önyarg1 becerisinin çoğunlukla olumsuz değerlendirilmesinde öğrenciyi dinlemeden peşin ve kesin hüküm verme; eşit yaklaşabilme becerisinin çoğunlukla olumsuz değerlendirilmesinde bazı öğrencilere daha fazla önem verme, kadın-erkek eşitliğine dikkat etmeme ve din, dil, ırk ayrımı yapma; hitabet becerisinin çoğunlukla olumsuz değerlendirilmesinde ise sınıfa yeterince hâkim olamama ve ses tonunu etkili kullanamama gibi deneyimlerin etkili olduğu tespit edilmiştir. Eşit olma konusunda K46 ve K74'ün şu cümleleri dikkat çekicidir;

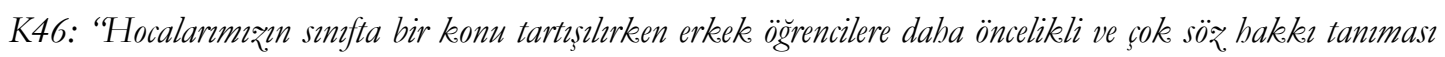
bu konuda bakkinda maalesef bizim de önyargil olmamiza sebep oluyor."

K74: “... Yine bir hocamı var, çok iyi bir hoca ama yabanclardan nefret ediyor galiba. Hep yabanclara

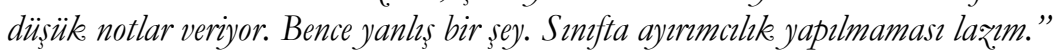

Katıllımclar, öğretim elemanlarının iletişim becerilerine yönelik diğer deneyimlerinde ise hocaların çoğunluğunun somut açık ve net konuşmadığını; ayrıca eleştiriye de açık olmadıklarını vurgulamışlardır. Katılımcıların, öğretim elemanlarının uygun göz teması kurma ve sözel ve sözel olmayan davranışları uyumlu kullanma becerilerinde ise çoğunlukla olumlu deneyimlere sahip olduğu bulunmuştur.

\section{İletişim Konusunda Öğretim Elemanlarından Beklentiler}

Araştırmada elde edilen bulgulara göre katılımcıların iletişim sürecinde öğretim elemanlarından beklentilerine yönelik görüşleri, en sık tekrar edilen iletişim becerisinden en az tekrar edilen iletişim becerisine doğru sayısallaştırılarak Tablo 2'de sunulmuştur. 
Tablo 2. İletisim Sürecinde Ögretim Elemanlarndan Beklentiler

\begin{tabular}{lc}
\hline Beceriler & Toplam \\
\hline Empati kurma & 45 \\
Anlayışlı ve hoşgörülü davranma & 41 \\
Saygilı olma & 31 \\
Etkin dinleme & 30 \\
Beden dilini etkili kullanma & 30 \\
Hitabet & 26 \\
Önyargıdan uzak olma & 17 \\
Özsaygı geliştirici dil kullanma & 12 \\
Somut, açık ve anlaşıllır konuşma & 11 \\
Kilık-kıafete dikkat etme & 7 \\
Sözel ve sözel olmayan davranışları uyumlu kullanma & 6 \\
Türkçeyi etkili kullanma & 6 \\
Somut konuşma & 5 \\
Ben dili kullanma & 5 \\
Elesstiriye açı olma & 5 \\
Eşit davranma & 4 \\
Samimi yaklaşma & 2 \\
Açık görüşlü olma & 1 \\
Baskııı olmama & 1 \\
\hline Toplam & $\mathbf{2 8 5}$ \\
\hline
\end{tabular}

Tablo 2 incelendiğinde, katılımcıların iletişim sürecinde öğretim elemanlarından en çok görmeyi istedikleri beceriler sırasıyla empati, anlayışlı ve hoşgörülü olma, saygılı olma, etkin dinleme, beden dilini etkili kullanma ve hitabet üzerine yoğunlaştığı görülmektedir. Ayrıca katılımcılar, öğretim elemanlarının önyargısız olmasını, özsaygı geliştirici bir dil kullanmasını, somut, açık ve anlaşılır konuşmasını beklediklerini de sıklıkla dile getirmişlerdir. Katıllımclar, öğretim elemanlarının empati becerisini etkin bir biçimde kullandıkları zaman öğrencilerinin bakış açılarını, duygu ve düşüncelerini doğru algılayabileceğini düşünmektedirler. Örneğin kattlımclardan K14'ün "Hocalardan iletişim konusundaki beklentim genel olarak. empati kurmalardir. Ögrenciler ile aralarnda empati kurarlarsa birbirlerini daba iyi anlayabileceklerini dïsünüyorum." şeklindeki ifadeleri bahsi geçen bulguları destekler niteliktedir. Ayrıca anlayışıı ve hoşgörülü olma becerisinin etkin kullanılması sayesinde hocaların ortaya çıan sorunları daha iyi algılayabileceklerini, daha sabırlı, öğrencileri küçümsemeyen ve hor görmeyen bir yapıya sahip olacaklarını düşünmektedirler. Katılımcıların anlayışlı ve hoşgörülü olma becerisine yönelik ifadelerinden bazıları şöyledir;

K22: "Bir soru sorduğumuzda anlayışh olmalar gerektig̈ini düsünüyorum. Not alurken bir yeri kaçımp sorduğumda anlattum dinleseydin diye bir cevapla karşzlaștım. Bu durum sonunda o ögretim üyesiyle aramda bir duvar olustuğunu sö̈leyebilirim. ..."

K40: "Hocalarn daha anlayış̧ olmalarmı, küçümseyici ve aşağglayncı kelimeler kullanmamalarm isterdim. ..."

Katılımcıların, öğretim elemanlarından sahip olmalarını bekledikleri en sık tekrar edilen diğer beceriler sayg1 ve etkin dinleme becerileridir. Katılımcıların saygılı olma becerisine yönelik ifadelerinde genellikle öğrenciden ziyade bir birey olarak dikkate alınma, koşulsuz değer görme, yargılanmama, eleştirilmeme ve alay edilmeme gibi konular üzerinde durulduğu anlaşılmaktadır. Katılımcılardan K63'ün "Kesinlikle hocalarn ögrencilere sayg duymasım isterdim. Hocalar kendilerini büyük görüp ögrencilere sayg duymuyorlar. En alt seviyede ögrencileri görüyorlar. Bence sayg iletiş̧im için zemini oluşturan unsurdur." cümleleri saygilı olma becerisinin öğrenciler için ne denli önemli olduğunu göstermektedir. Katılımcıların, etkin dinleme becerisine yönelik olarak ise öğrenciye sayg1 duyduğunu ve değer verdiğini gösterebilmek, öğrencinin aktarmak istediği mesaj1 daha iyi anlayabilmek, dönüt vermek ve olası sorunların ortaya çıkmasını engellemek için iletişimde etkin dinleme becerisinin önemli olduğunu düşündükleri belirlenmiştir. Katılımcılardan bazılarının etkin dinleme becerisine yönelik görüşleri şöyledir;

K7: "İletisim becerilerinden en önemlilerinden biri de etkin dinlemektir. Hocalarmmazun bu beceriye sabip olmalar gerekir. Cü̈nkï dinlemek karşıdaki kişsiye değer verdiğinin ve saygz duyulduğunu bir göstergesidir. Karşımı̨̊daki kişsiyi anlamanm ilk basamağ iyi ve etkili dinlemektir."

K30: "İletişim kurabilmemiz için etkin dinleme ve anlaşsllir geri dönüt vermeye sahip olmahdirlar. Bu sayede biz. mesajmiz? iletirken ve bize geri mesaj gelirken sorun yașamamış oluru‡:" 
K39: "İyi bir iletişim için ögrretmen öğrencisine dĕger verdig̈ini hissettirmeli, görïsler ne olursa olsun hoşgörü cerçevesinde dinleyerek onlar önemsedig̈ini göstermelidir."

Empati kurma ve anlayışlı/hoşgörülü davranma becerisinden sonra katıllımcıların, öğretim elemanlarından sahip olmalarını bekledikleri diğer beceriler ise beden dilini etkili kullanma ve hitabettir. Katılımcılar beden dilini etkili kullanma ve hitabet becerisine yönelik beklentilerinde genel olarak derslerin etkili geçmediğini, hocalarını pek duyamadıklarını, belirli bir ses tonu üzerinden giden derslerin daha sıkıcı olduğunu, jest ve mimiklerin veya göz temasının kurulmamasının kendilerini dersten ve iletişimi sürdürme konularında zorladıklarını ifade etmişlerdir. Katılımcılardan K5 beden dilinin ve hitabet becerisinin etkin kullanımına yönelik beklentisini daha önce yaşadığı olumsuz bir deneyimi ifade ederek paylaşmıştır. K5'in konu hakkındaki görüşü şöyledir;

K5: "Dersi anlattrken ses tonlarm ve mimiklerini kullanarak ders anlatmalarm isterim. Çünkü beden dilini etkili kullanmadan, mimiklerini kullanmadan işlenen derste konunun pek fąla anlaşlliğgrn düssünmüyorum. Başladığ gibi devam edip giden bir derste bütün sinnf uyku moduna gecmis oluyor. Bu yürdende el kol bareketleri kullanarak ve konunun önemli yerinde de ses tonuna vurgu yaparak anlatulmasi taraftaryzm."

Katıllımclar tarafindan öğretim elemanlarının sahip olması beklenilen ve en sık tekrar edilen diğer beceriler ise önyargısız olma, özsaygı geliştirici dil kullanma ve somut, açık ve anlaşır bir dil kullanmadır. Önyargısız bir iletişim isteyen öğretmen adayları, kendilerini ifade etmeye imkân tanınmadığını ve öğretim elemanlarının zihinlerindeki belirli kişilere, durumlara veya olaylara önyargılı bir biçimde yaklaştığını ve bu yönde kararlar aldıklarını ifade etmişlerdir. Katılımcılardan K68 ve K76'nın önyargı konusundaki görüşleri ve beklentileri sırasıyla şöyledir; "Bazen hocalar bįlere ön yarghl bir șekilde yaklaşabiliyorlar. Sorularna biz, cevap

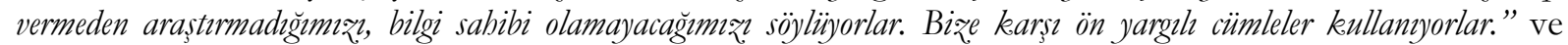

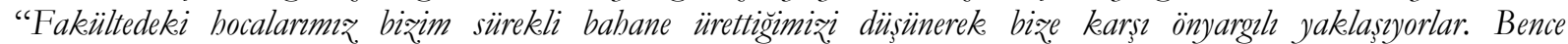

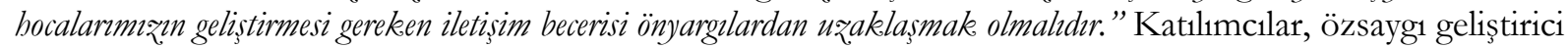
dil kullanma konusunda ise öğretim elemanlarının öğrencilere yaklaşımlarında üslûba dikkat etmelerini, hakaret veya suçlayıcı tavır içerisinde olmamalarını, değersiz hissetmelerine neden olacak davranışlardan kaçınmalarına ve özgüvenlerini zedelemeyen bir yaklaşımda bulunmalarını beklemektedirler. Öğretmen adaylarının somut, açık ve anlaşır bir dil kullanımına yönelik beklentilerinde ise akademik dilin, terimlerin veya kavramların yoğunlukla kullanılmasının iletişimde problem yarattığı sonucu öne çıkmaktadır. Katılımcıların öğretim elemanlarından etkin bir iletişim için diğer beklentileri ise sırasıyla kıllk-kıyafete dikkat etme, sözel ve sözel olmayan davranışları uyumlu kullanma, Türkçeyi etkili kullanma, ben dilini kullanma, eleştiriye açık olma, eşit davranma, samimiyet gösterme, açık görüşlü olma ve baskıcı olmamadır.

\section{Sonuç, Tartışma ve Öneriler}

Eğitim fakültelerinde öğretmen yetiştiren öğretim elemanlarının sahip olduğu iletişim becerilerinin, öğretmen adaylarının perspektifinden incelendiği bu araştırmanın sonuçları temel olarak iki boyutta ele alınmıştır. Bunların birincisi öğretim elemanlarının iletişim becerilerinin olumlu ve olumsuz yönden değerlendirilmesi; ikincisi ise öğretmen adaylarının iletişim konusunda öğretim elemanlarından beklentileridir.

$\mathrm{Bu}$ çerçevede elde edilen sonuçlara göre, öğretmen adaylan öğretim elemanlarının iletişim becerilerini genel itibariyle olumsuz yönde değerlendirmişlerdir. Araştırma sonuçlarına göre öğretim elemanlarının en fazla olumsuz yönde değerlendirilen ya da zayıf bulunan iletişim becerileri; empati kurma, etkin dinleme, anlayışı/hoşgörülü davranma, özsaygı geliştirici dil kullanma ve eleştiriye açı olmadır. Dolayısıyla öğretmen adaylarının bir kısmı ders aldıkları öğretim elemanlarının empati kuramadıklarını, yeterince anlayışı ve hoşgörülü olmadıklarını, etkin dinleyemediklerini, güçlü bir hitabet becerisine sahip olmadıklarını, bazen önyargılı olabildiklerini, tüm öğrencilere eşit yaklaşamadıklarını ve çoğu zaman eleştiriye açık olmadıklarını vurgulamaktadırlar. Buna karşın öğretim elemanlarının en olumlu yönde değerlendirilen iletişim becerileri ise eğitim-öğretim faaliyetleri için dış görünüşe önem verip uygun kilıkkıyafet seçebilme ve Türkçeyi doğru kullanmadır. Öğretmen adaylarının bu değerlendirmelerine göre genel olarak öğretim elemanları iletişim sürecinde özellikle kılık kıyafet konusunda dikkatlidirler ve Türkçeyi etkili kullanmaktadırlar. Ayrıca çoğunlukla saygı çerçevesinde iletişim kurdukları ve göz temasına önem verdikleri anlaşılmaktadır.

Araştırmada ulaşılan bir diğer sonuca göre öğretmen adayları, öğretim elemanlarının diksiyonları ve akıcı konuşmalarında da bazı problemler olduğunu düşünmektedirler. Başta Fen Bilgisi ve İngilizce bölümünde okuyan öğretmen adayları olmak üzere genellikle öğretim elemanlarının özsayg1 zedeleyici dil 
kullandıklarını düşünmektedirler. Buna karşın azınlıkta da olsa öğretim elemanlarının özsaygı geliştirici dil kullandığını ifade eden öğretmen adayları da bulunmaktadır. Buna ek olarak öğretim elemanlarının küçük bir kısmı lâkap takma, aşağılama gibi davranışlar sergiliyor olsa da genellikle insan ilişkilerinde saygı değerine önem verdikleri araştırmadan elde edilen bir diğer sonuçtur. İlkokul, ortaokul, lise ve üniversite gibi çeşitli eğitim düzeylerinde ve farklı branşlarda görev yapan öğretmen veya öğretim elemanlarının iletişim becerilerini konu alan araştırma sonuçları ögretmenlerin /öğretim elemanlarının iletişim becerilerinin ya da iletişim becerilerine ilişkin algılarının yüksek düzeyde olumlu olduğunu göstermektedir (Aküzüm ve Özdemir Gültekin, 2017; Altınkurt, 2003; Aslan Bağc1 ve Efilti, 2019; Baydar Posluoğlu, 2014; Cantekin, 2009; Çetinkaya, 2013; Derici Cevap, 2017; Günay, 2003; Günbay1, 2007; Kadıoğlu Ateş ve Bulut, 2019; Kılıç, 2013; Küpeli; 2019; She, \& Fisher, 2000; Şimşek ve Bakır, 2019; Uzun, Özdem ve Kara, 2018; Yılmaz, Yoncalık ve Çimen, 2010). Ay'ın (2016) çalışmasında öğretmenlerin öğrencileriyle motive edici, anlayışlı, güler yüzlü, samimi ilişkiler kurdukları, katılımcı ve eğlenceli ders işledikleri sonuçlarına ulaşılmıştır. Benzer şekilde Şimşek ve Bakır'n (2019) çalışmalarında öğretmenlerin ses tonunu etkili kullanma, öğrencilerle göz teması kurma, kılık kıyafet konusunda özenli davranma ve beden dilini etkili kullanma gibi olumlu iletişim davranışları gösterdikleri sonucuna ulaşılmıştır. Avanoğlu'nun (2018), Bozkurt Bulut'un (2004), Kayhan'ın (2014) ve Köleşoğlu'nun (2009) araştırmalarında ise öğretmenlerin iletişim becerilerinin orta düzeyde olduğu sonucuna ulaşılmıştır. Ancak Durukan ve Maden'in (2010) araştırma sonuçları ise öğretmenlerin iletişim becerilerinin düşük seviyede olduğunu göstermektedir. Her ne kadar araştırmaların genelinde öğretmen ve öğretim elemanlarının iletişim becerilerinin orta ve yüksek düzeyde olduğu sonucu ortaya çıksa da iletişim süreçlerinde öğretmenlerin yeterli görülmediğini veya geliştirilmesi gereken bazı iletişim becerilerinin olduğunu gösteren araştırmalar da dikkat çekmektedir. Örneğin bu çalışmanın sonuçlarına benzer olarak Keçeci’nin (2009) yaptığı çalışmada öğrenciler, öğretim elemanlarının iletişim konusunda en az empati becerisini gösterdiklerini ifade etmişlerdir. Bu çalışmada ulaşılan başka bir sonuç da öğretmen adaylarının, öğretim elemanlarını sözlü iletişimde genel olarak başarılı buldukları ancak uygun jest ve mimik kullanma, dönüt verme ve empatik dinleme süreçlerinde ise yetersiz kaldıklarını düşünmeleridir. Arslan'ın (2011) yaptığı araştırmada da öğrencilerin öğretim elemanlarının dinleme becerilerini diğer iletişim becerilerine göre zayıf buldukları tespit edilmiştir. Benzer şekilde Kaya, Sungurtekin ve Deniz (2017) de yaptıkları çalışmada öğretim elemanlarının, öğrencileri dinleme düzeylerinin düşük olduğu sonucuna ulaşmışlardır. Arslantaş'ın (2012) yaptığı araştırmada üniversite öğrencilerinin öğretim elemanlarının yarısını iletişim becerisi açısından yeterli görmedikleri ortaya konulmuştur. Çetinkanat (1998) ise öğretmenlerin; empati, saydamlık, eşitlik, etkililik ve yeterlilik olmak üzere tüm boyutlarıly iletişim becerilerini geliştirmeleri gerektiği sonucuna ulaşmıştır. Benzer şekilde Çetinkaya’nın (2013) araştırmasında öğretmenlerin iletişim yeterlik algılarının genel olarak yeterli olduğu ancak beden dilini etkili kullanma, etkin dinleme, anlaşılabilirlik ve empati boyutlarında kendilerini eksik gördükleri sonucuna ulaşılmıştır. $\mathrm{Bu}$ araştırmanın ve literatürdeki araştırmaların sonuçları birlikte değerlendirildiğinde her düzeyde öğretim faaliyetlerini yürüten öğretmenlerin ve öğretim elemanlarının sahip oldukları iletişim becerilerinde geliştirilmesi gereken veya yeterli olmayan birtakım özelliklerin olduğu söylenebilir. Bu genel sonucu destekleyen daha önceki bir çalışmada da benzer bulgulara ulaşılmıştır. Buna göre öğretim elemanları bazı etkili iletişim becerilerine sahip olmakla birlikte yetersiz oldukları ve güçlendirmeleri gereken iletişim becerilerinin olduğu vurgulanmıştır (Yılmaz vd., 2010, s. 57).

Araştırmanın ikinci boyutunda elde edilen sonuçlara göre, öğretmen adayları iletişim sürecinde öğretim elemanlarından empati kurmalarını, anlayışlı ve hoşgörülü olmalarını, öğrencilerini etkin dinlemelerini, hitabet ve beden dilini etkili kullanmalarını, saygılı olmalarını, öğrencilere karşı önyargısız, sade, açık, anlaşııı ve özsaygı geliştirici bir dil kullanmalarını beklemektedirler. Araştırmanın ilk boyutundan elde edilen sonuçlarla birlikte düşünüldüğünde bu sonuçların daha anlaml hale geldiği söylenebilir. Nitekim öğretmen adayları öğretim elemanlarının iletissim becerileri ile ilgili eksikliklerini dile getirmekle birlikte bu eksikliklerin giderilmesine yönelik beklenti içerisindedirler. Yani sonuçlar incelendiğinde öğretim elemanlarının birinci temada olumsuz olarak değerlendirilen iletişim becerileri ile ikinci temada öğretim elemanlarından göstermeleri beklenilen becerilerin ortak olduğu ve büyük ölçüde benzerlik gösterdiği anlaşılmaktadır. Buna göre birinci temada olumsuz olarak değerlendirilen ve ikinci temada da beklenti içinde olunan ortak becerilerin en dikkat çekici olanları empati kurma, etkin dinleme, anlayışlı ve hoşgörülü olma, özsaygı geliştirici dil kullanma ve önyargıdan uzak olmadır. Burada öğretmen adaylarının öğretim elemanlarılla sınıf içi ve dışında yaşadıkları olumsuz deneyimlerin bu beklentilere yol açtığı söylenebilir. Bir diğer çarpıc1 sonuç ise iletişimde saygılı olabilme becerisi konusunda öğretim elemanları birinci temada çoğunlukla olumlu yönde değerlendirilmişlerdir. Buna rağmen söz konusu beceri aynı zamanda ikinci temada da öğretim elemanlarından en çok görmek istedikleri beceriler arasında yer 
almıştır. Bu çelişki, öğretmen adaylarının iletişimde saygının her daim olmazsa olmaz bir beceri olarak düşündüklerini göstermektedir. Literatür incelendiğinde eğitim fakültesinin farklı bölümlerinde öğrenim gören öğretmen adayları ile diğer fakültelerde öğrenim gören öğrencilerin derslerine giren öğretim elemanlarından iletişim alanında beklentileri benzerlik göstermektedir. Örneğin Özdemir ve Üzel'in (2010, s. 146) yaptığı araştırmada ilköğretim matematik öğretmen adaylarının öğretim elemanlarında en çok aradıkları özellikler sevecen olma, ders dışında da öğrenciyle iletişim kurma ve dersleri eğlenceli işleyebilme gibi davranışlardır. Ergün, Duman, Kıncal ve Arıbaş’ın (1999) yaptıkları "İdeal Bir Öğretim Elemanının Özellikleri” adlı araştırma sonuçlarına göre üniversite öğrencileri özellikle kendilerine saygı duyulmasını istemektedir. Azarlayan, hakaret eden, küçük düşüren, hor gören tutum ve davranışları değil; öğrencileri değerli kabul eden, onların sözünü dinleyen, nazik ve samimi davranan, kibirli davranmayan hoca profilini görmeyi arzu etmektedirler (Arslantaş, 2011; Ergün vd., 1999). Benzer şekilde birçok çalışmada genel olarak öğrencilerin öğretim elemanlarından etkili ve yeterli kişilerarası becerileri gösterme, sabırlı ve hoşgörülü olma, rol modeli olma ve kaynak kişi olma gibi nitelikleri bekledikleri ortaya çıkarılmışır (Ergün vd., 1999; Gedik-Dinç ve Gizir, 2019). Genel olarak öğretmen adayları tarafindan öğretim elemanlarının yetersiz bulunan ya da karşıllklı etkileşim sürecinde göstermeleri beklenilen iletişim becerilerinin çoğunlukla demokratik davranış biçimleriyle yakından ilişkili olduğu görülmektedir. Özellikle anlayışlı / hoşgörülü olma, karşıdakine saygı duyma, etkin dinleyerek anlamaya çalışma ve özsayg1 geliştirici dil kullanarak iletişim kurma gibi beceriler özünde demokratik değerlerle birebir ilişkilidir. Dolayısıyla her şeyden önce öğretim elemanlarının derslerinde demokratik bir sınıf atmosferi oluşturmaları sağlıklı bir iletişim için temel anahtardır. Böyle bir sınıf ortamında öğretim elemanları tarafindan sergilenecek olan iletişim becerilerinin, öğrencilerin duygu, düşünce, tutum ve davranışlarını olumlu yönde etkileme ihtimali daha yüksektir. Aksi takdirde sınıf içinde veya dışında istenmeyen davranışların görülme sıklı̆̆ artabilir. Bilindiği gibi öğretim sürecinde öğrencileri rahatsız eden ve onların öğrenmelerini engelleyen her türlü davranış "istenmeyen davranışlar" olarak adlandırılır ve bunlar öğretim elemanı kaynaklı olabilir. Aşağıllama, bağırma, görmezden gelme, ters bakma, fiziksel şiddet gösterme ve ayrımcilık yapma (Kearney, Plax, Hays ve Ivey, 1991, s. 314-315) gibi sıkça tekrarlanan istenmeyen davranışlar, kaliteli öğrenme açısından kritik role sahip olan iletişimi olumsuz yönde etkilemektedir. Literatürdeki çalışmalar, farklı gerekçe ve nedenlerle öğretim elemanlarının söz konusu istenmeyen davranışları sergileyebildiklerini göstermektedir (Bolkan ve Goodboy, 2013; Özer ve Bozanoğlu, 2016). Samanc1 ve Yıldırım (2015) tarafından yapılan araştırma bulguları incelendiğinde öğretmen adayları öğretim elemanlarının ayrımcılık yapma, öğrenci düşüncesini önemsememe ve sınıfta katı otorite uygulama davranışlarını sergilemelerini öğretim elemanlarının demokratik olmayan tutum ve davranışları arasında göstermişlerdir. Gedik-Dinç ve Gizir'in (2019) yaptığı araştırmada ise bazı öğretim elemanlarının öğrencilere karşı küçümseyici ve azarlayıcı dil kullandıkları bulgusuna ulaşılmıştır. Öğretim elemanları tarafindan demokratik sınıf ortamına aykırı olarak yapılan uygulamalara ilişkin tüm bu sonuçlar, aynı zamanda öğrencilerin öğretim elemanlarının iletişim becerileri ile ilgili düşüncelerini de olumsuz yönde ve derinden etkileyebileceğini göstermektedir.

İletişim süreci algılama ile başlar. İnsanların algısını ise içinde bulunduğu psikolojik durum, yaşadığı toplum ve kültürel değerler doğrudan etkileyebilmektedir. Dolayısıyla bu araştırmada her ne kadar öğretmen adaylarının değerlendirmelerini yaparken nesnel olmaları istenmiş olsa da aslında değerlendirmelerinin öznel olduğunu söylemek mümkündür. Analiz edilen verilerde, aynı sınıfta ve bölümde öğrenim gören öğrencilerin derslerine giren öğretim elemanlarının iletişim becerileri için çok farklı değerlendirmelerde bulunmaları bunun kanıtıdır. Bu nedenle öğretmen adaylarının kısa ya da uzun süreli duygusal durumları onların değerlendirmeleri üzerinde etkili olmuş olabilir. Örneğin bir öğretmen adayı, bir öğretim elemanıyla yaşadığı iletişim problemini tüm öğretim elemanlarına genelleyerek olumsuz yorumlar yapmış olabilir. Özellikle bu araştırmanın verileri, Covid-19 salgını sebebiyle ülkemizdeki tüm üniversitelerin uzaktan eğitime geçtiği 2019-2020 bahar döneminde toplanmıştır. Bu süreçte öğretmen adayları, derslerine giren ögretim elemanlarını hem yüz yüze derslerin işlendiği dönemleri hem de pandemi döneminde uzaktan eğitim sürecindeki deneyimlerini dikkate alarak değerlendirmişlerdir. Dolayısıyla öğretmen adaylarının iletişim konusunda yaptıkları özellikle olumsuz değerlendirmeler üzerinde bu sürecin getirdiği psikolojik etkinin olma ihtimalini belirtmek gerekir. Çünkü karantina sürecinin kayg1yı ve stresi arttırdığı (Karadeniz ve Zabc1, 2020, s. 302; Öztürk, Akalın, Özgüner ve Şakiroğlu, 2020, s. 888) insanların psikolojisi üzerinde orta ve şiddetli etkileri olduğu bilinmektedir (Taylor, Agho, Stevens ve Raphael, 2008, s. 347). Hatta Covid-19 salgınının şiddetli yaşandığı dönemlerde yapılan bir çalışmada bu süreçte insanların olumlu duygularında azalma, olumsuz duygularında ise artma eğilimi olduğu belirlenmiştir (Li, Wang, Xue, Zhao ve Zhu, 2020, s 1). Ayrıca yine bu dönemde uzaktan eğitim sürecinde yaşanan problemleri ele alan 
birçok çalışmada özellikle öğrencilerin öğretim elemanlarılla olan iletişimlerinin genel olarak zayıfladığı, iletişim kurmada ve dönüt almada sorunlar yaşadıkları, ayrıca sanal ortamdaki derslerden sıkılabildikleri ve motivasyon eksikliği oluştuğu belirlenmiştir (Bakioğlu ve Çevik, 2020, s. 118; Erzen ve Ceylan 2020, s. 240; Yolcu, 2020, s. 244-245). Elbette tüm bunlar öğrencilerin bireysel görüşleri üzerinde etkili olabileceği gibi öğretim elemanları da aşırı iş yükü, yaşadıkları çeşitli ailesel ya da yönetimsel problemler, deneyimsizlik, ögrenci ilgisizliği ve kalabalık sınıflar (Boz, 2020, s. 37) gibi birçok olumsuz faktörün etkisiyle iletişim becerilerini istenilen şekilde sergilemede sorun yaşıyor olabilirler. $\mathrm{O}$ halde bu araştırma sonucunda ortaya çıkan değerlendirmeleri tüm öğretim elemanlarına genellemek söz konusu değildir.

Sonuç itibariyle bu araştırmada öğretmen adaylarının gözünden bakıldı̆̆ında derslerine giren öğretim elemanları bazı güçlü iletişim becerilerine sahip olmakla birlikte zayıf oldukları ve geliştirmeleri gereken iletişim becerilerinin daha fazla olduğu sonucuna ulaşılmıştır. Elbette öğretim elemanları arasında iletişim becerileri açısından bireysel farklılıklar vardır ve yine öğretmen adaylarının değerlendirmelerinde önyargılar ve öznel bakış açıları söz konusudur. Ancak genel itibariyle ortaya çıkan sonuçların bizlere önemli ipuçları verdiğini de kabul etmek gerekir. Dolayisıyla öğretmen yetiştiren kurumlarda derslere giren öğretim elemanlarının iletişim becerilerini geliştirmeye açı olmaları ve bu konuda önlem almaya yönelik çaba göstermeleri eğitim-öğretimin niteliğine katk1 sağlayabilir. Bundan sonraki çalışmalarda daha geniş bir örneklem grubu ile nicel çalışmalar yapılabilir. Ayrıca doğrudan öğretim elemanlarının kendi görüşlerine başvurularak iletişim becerileri konusundaki farkındalıklarının ya da öz-yeterliklerinin belirlenmesi bu konudaki literatüre katkı sağlayabilir.

\section{Etik Beyan}

"Ë̆itim Fakültesi Ögretim Elemanlarmm İletisim Becerileri: Ögretmen Adaylarmm Perspektifinden Bir Değerlendirme Calıs̆ması" başlıklı çalışmanın yazım sürecinde bilimsel kurallara, etik ve alıntı kurallarına uyulmuş; toplanan veriler üzerinde herhangi bir tahrifat yapılmamış ve bu çalışma herhangi başka bir akademik yayın ortamına değerlendirme için gönderilmemiştir. Gerekli olan etik kurul izinleri Ondokuz Mayıs Üniversitesi Sosyal ve Beşeri Bilimler Etik Kurulu'nun 25.12.2020 tarih, 11 sayılı toplantısında 2020/808 nolu karar ile alınmıştır.

\section{Kaynakça}

Akgün, R. ve Çetin, H. (2018). Üniversite öğrencilerinin iletişim becerilerinin ve empati düzeylerinin belirlenmesi. MANAS Sosyal Arassturmalar Dergisi, 7(3), 103-117. Erişim adresi: https://dergipark.org.tr/en/pub/mjss/issue/43001/520543

Aküzüm, C. ve Özdemir Gültekin, S. (2017). Sınıf öğretmenlerinin iletişim becerileri ile sınıf yönetimi becerileri arasındaki ilişkinin incelenmesi. Elektronik Eğitim Bilimleri Dergisi, 6(12), 88-107. Erişim adresi: https://dergipark.org.tr/tr/pub/ejedus/issue/31928/336132

Akyol, P. (2019). Farklı fakültelerdeki öğrencilerin iletişim becerilerinin karşılaştırlması. Spor Eğitim Dergisis, 3(3), 71 77. Erişim adresi: https://dergipark.org.tr/tr/pub/seder/issue/48470/622636

Aliusta, Z., Akmanlar, Z. ve Gökkaya, F. (2019). Üniversite öğrencilerinin iletişim becerileri ve sosyal medya bağımlılı̆ı arasındaki ilişsinin incelenmesi. Anadolu Psikiyatri Dergisi, 20(1), 10-13. https://doi.org/10.5455/apd.302644847

Altınkurt, Y. (2003). Endüstri meslek liselerinde görev yapan ögrretmenlerin simf yönetimi çerçevesinde iletişim özelliklerinin belirlenmesi (Yüksek Lisans Tezi). Anadolu Üniversitesi Eğitim Bilimleri Enstitüsü, Eskiş̧ehir.

Arbaugh, J. B. (2001). How instructor immediacy behaviors affect student satisfaction and learning in web-based courses. Business Communication Quarterly, 64(4), 42-54. Erişim adresi: https://journals.sagepub.com/doi/abs/10.1177/108056990106400405

Arslan, F. (2011). Simf yönetiminde ögretim elemanlarmm iletisim davranıslarna ilişkin ögrenci görïsleri (Selçk üniversitesi ilabiyat fakültesi örneği) (Yayımlanmamış yüksek lisans tezi). Selçuk Üniversitesi Sosyal Bilimler Enstitüsü, Konya.

Arslantaş, H. İ. (2011). Öğretim elemanlarının öğretim stratejileri-yöntem ve teknikleri, iletişim ve ölçme değerlendirme yeterliklerine yönelik öğrenci görüşleri. Mustafa Kemal Üniversitesi Sosyal Bilimler Enstitiisï Dergisi. (8)15, 487-506. Erişim adresi: https://dergipark.org.tr/en/pub/mkusbed/issue/19555/208686

Aslan Bağcl, Ö. ve Efilti, E. (2019). Özel eğitim okullarında görev yapan öğretmenlerin iletişim becerilerinin incelenmesi. Turkish Studies, 14(3), 335-349. https://doi.org/10.29228/TurkishStudies.22659

Avanoğlu, E. (2018). Öğretmenlerin iletişim becerileri ile moralleri arasindaki ilişkinin incelenmesi (Yayımlanmamış yüksek lisans tezi). Kastamonu Üniversitesi Sosyal Bilimler Enstitüsü, Kastamonu.

Ay, D. (2016). Ögretmenlerin kişilerarast öz yeterlikleri ve informal iletişimleri: bir karma yöntem çalssması (Tokat ili örneği) (Yüksek Lisans Tezi). Cumhuriyet Üniversitesi Eğitim Bilimleri Enstitüsü, Sivas.

Bakioğlu, B. ve Çevik, M. (2020). COVID-19 pandemisi sürecinde fen bilimleri öğretmenlerinin uzaktan eğitime iliş̧kin görüşleri. Turkish Studies, 15(4), 109-129. Erişim adresi: https://dx.doi.org/10.7827/TurkishStudies.43502 
Bakır, S. (2019). Türkçe öğretmeni adaylarının etkili iletişim becerileri ile sorgulama becerileri arasındaki ilişkinin çeşitli değişkenler açısından incelenmesi. Akdeniz Eğitim Araştırmalar Dergisi, 13(30), 398-414. Erişim adresi: https://doi.org/10.29329/mjer.2019.218.22

Barker, L. R. (1999). The Social Work Dictionary. USA: NASW Press.

Baydar Posluoğlu, F. D. (2014). Illkokul ögrretmenlerinin iletişim yeterlilikleri ile empati kurma becerileri arasindaki ilişkinin incelenmesi (Yüksek Lisans Tezi). Yeditepe Üniversitesi Eğitim Bilimleri Enstitüsü, İstanbul.

Baykara Pehlivan, K. (2005). Öğretmen adaylarının iletişim becerisi alg1ları üzerine bir çalışma. İlkëğretim Online, 4(2), 17-23. Erişim adresi: http://ilkogretim-online.org.tr/index.php/io/article/viewFile/2014/1850

Bolkan, S. ve Goodboy, A. K. (2013). No complain, no gain: Students' organizational, relational, and personal reasons for withholding rhetorical dissent from their college instructors. Communication Education, 62(3), 278300. Erişim adresi: https://www.tandfonline.com/doi/pdf/10.1080/03634523.2013.788198? needAccess=true

Bozkurt Bulut, N. (2004). İlköğretim sınıf öğretmenlerinin iletişim becerilerine ilişkin algılarının çeşitli değişkenler açısından incelenmesi. Türk Eğitim Bilimleri Dergisi, 2(4), 443-452. Erişim adresi: https://dergipark.org.tr/en/pub/tebd/issue/26126/275206

Cantekin, Ö. F. (2009). Genel liselerde görev yapan İniliz̧ce ögretmenlerinin mesleki ve iletişimsel yeterlikleri (Doktora Tezi). Gazi Üniversitesi Ĕgitim Bilimleri Enstitüsü, Ankara.

Çakır, H. ve Ünal, U. (2019). İletişim becerilerini inşa eden faktörlerle ilgili iletişim fakültesi öğrencileri üzerine karşılaştırmalı bir analiz. Erciyes İletişim Dergisi, 6(2), 929-954. https://doi.org/10.17680/erciyesiletisim.559907

Çetinkanat, C. (1998). Öğretmen adayları ve müfettişlerin bakış açısından öğretmen iletişim becerileri. Kuram ve Uygulamada Eğitim Yönetimi Dergisi, 4(14), 209-221. Erişim adresi: http://kuey.net/index.php/kuey/article/view/639

Çetinkaya, E. (2013). Meslek lisesi ögretmenlerinin iletişimsel yeterlik düzeyleri (V ak'a incelemesi, Yuldirm Ticaret Meslek Lisesi) (Yüksek Lisans Tezi). Uludağ Üniversitesi, Eğitim Bilimleri Enstitüsü, Bursa.

Çetinkaya, Z. (2011). Türkçe öğretmen adaylarının iletişim becerilerine ilişkin görüşlerinin belirlenmesi. Kastamonu Ë̈itim Dergisi, 19(2), 567-576. Erişim adresi: https://dergipark.org.tr/tr/pub/kefdergi/issue/49052/625770

Derici Cevap, S. (2017). Sinf öğretmenlerinin benlik saygilar ile iletişim becerileri arasindaki iliş̧kinin çeşitli değişkenler açısindan incelenmesi (Eskil örneği) (Yüksek Lisans Tezi). Necmettin Erbakan Üniversitesi Eğitim Bilimleri Enstitüsü, Konya.

Dilekman, M., Başçı, Z. ve Bektaş, F. (2008). Eğitim fakültesi öğrencilerinin iletişim becerileri. Atatürk Üniversitesi Sosyal Bilimler Enstitüsü Dergisi, 12(2), 223-231. Erişim https://dergipark.org.tr/tr/pub/ataunisosbil/issue/2822/38075

Durukan, E. ve Maden, S. (2010). Türkçe öğretmenlerinin iletişim becerileri üzerine bir araştırma. Sosyal Bilimler Araștırmalar Dergisi, 5(1), 59-74. Erişim adresi: https://dergipark.org.tr/en/pub/gopsbad/issue/48556/616514

Ergün, M., Duman, T., Kıncal, R. Y. ve Arıbaş, S. (1999) İdeal bir öğretim elemanının özellikleri Afyon Kocatepe Üniversitesi. Sosyal Bilimler Dergisi. 3, 1-11. Erişim adresi: http://mustafaergun.com.tr/wordpress/wpcontent/uploads/2015/11/ergrup1.pdf

Erözkan, A. (2007). Üniversite öğrencilerinin iletişim becerilerini etkileyen faktörler. Marmara Üniversitesi Atatürk Eğitim Fakültesi Eğitim Bilimleri Dergisi 22, 135-150. Erişim adresi: http://dspace.marmara.edu.tr/handle/11424/1207

Erözkan, A. (2013). İletişim becerileri ve kişilerarası problem çözme becerilerinin sosyal yetkinliğe etkisi. Kuram ve Uygulamada Eğitim Bilimleri Dergisi, 13(2), 731- $745 . \quad$ Erişim https:/ / files.eric.ed.gov/ fulltext/EJ1017303.pdf

Erzen, E. ve Ceylan, M. (2020). Covid-19 salgını ve uzaktan eğitim: Uygulamadaki sorunlar. EKEV Akademi Dergisi, 24(84), 229-248.

Gedik-Dinç, R. ve Gizir, S. (2019). Öğrencilerin bakış açısından öğretim elemanlarının sınıf içindeki içindeki etik dışı davranışları. Yükesekögretim Dergisi, 9(1), 29-39. Erişim adresi: doi:10.2399/yod.18.033

Gilligan, T., Coyle, N., Frankel, R. M., Berry, D. L., Bohlke, K., Epstein, R. M., Finlay, E., Jackson, V. A., Lathan, C. S., Loprinzi, C. L., Nguyen, L. H., Seigel, C. ve Baile, W. F. (2018). Patient-clinician communication: American Society of Clinical Oncology consensus guideline. Obstetrical \& Gynecological Survey, 73(2), 96-97. https://doi.org/10.1097/01.ogx.0000530053.40106.9b

Günay, K. (2003). Simf yönetiminde iletişim becerilerinin değerlendirilmesi (Yüksek Lisans Tezi). Çukurova Üniversitesi Sosyal Bilimler Enstitüsü, Adana.

Günbay1, İ. (2007). Okullarda bir yönetim süreci olarak iletişim. Kuram ve Uygulamada Eğitim Bilimleri, 7(2), $765-798$. Erişim adresi: https://app.trdizin.gov.tr/publication/paper/detail/TnpFM01EUTA

Gürşimşek, I., Vural, E. E. ve Selçioğlu Demirsöz, E. (2008). Öğretmen adaylarının duygusal zekâları ile iletişim becerileri arasındaki ilişki. Mehmet Akif Ersoy Üniversitesi Eŭitim Fakültesi Dergisi, 16, 1-11. Erişim adresi: https:/ / scholar.google.com.tr/scholar?cluster $=17946844207577722689 \& \mathrm{hl}=$ tr\&as_sdt=0,5\&as_vis=1

Kadıoğlu Ateş, H. ve Bulut, R. C. (2019). Ortaokulda görev yapan öğretmenlerin iletişim becerileri ile örgütsel sinizm düzeyleri arasındaki ilişki. The Journal of Academic Social Science Studies, 75, 81-92. https://doi.org/10.9761/JASSS7991

Karadeniz, G. ve Zabcı, N. (2020). Pandemi döneminde uzaktan eğitim veren öğretmenlerin çalışma koşulları ve algıladıkları stres ile psikolojik iyi oluşları arasındaki ilişki. MSGSÜ Sosyal Bilimler Dergisi, 2(22), 301-3014. Erişim adresi: http://sosbildergi.msgsu.edu.tr/index.php/arsiv 
Kaya, M. F., Sungurtekin, D. ve Deniz, S. (2017). Üniversitelerde öğretim elemanı kaynaklı iletişim sorunları. Trakya Üniversitesi Eğitim Fakültesi Dergisi, 7(1), 176-195. Erişim https://dergipark.org.tr/en/pub/trkefd/issue/27304/287429

Kayhan, N. (2014). Öğretmenlerin iletişim becerileri ile çatısma yönetimi stratejileri arasındaki ilişki (Gaz̧iantep il örneğı) (Yüksek Lisans Tezi). Kahramanmaraş Sütçü İmam Üniversitesi Sosyal Bilimler Enstitüsü, Kahramanmaraş.

Kearney, P., Plax, T. G., Hays, E. R. ve Ivey, M. J. (1991). College teacher misbehaviors: What students don't like about what teachers say and do. Communication Quarterly, 39(4), 309-324. Erişim adresi: https://www.tandfonline.com/doi/abs/10.1080/01463379109369808

Kılıç, H. (2013). Sosyal bilgiler ögretmenlerinin iletişim becerilerinin belirlenmesi ve bą̧ değ̈̌şkenler açısından incelenmesi (Yüksek Lisans Tezi). Fırat Üniversitesi Eğitim Bilimleri Enstitüsü, Elâzı̆̆.

Koç Akran, S., Acıdemir, M. ve Uludağ, Ş. (2018). Üniversite öğrencilerinin iletişim kavramına yönelik metaforik alg1ları. E-Kafkas Eğitim Araştırmalar Dergisi, 5(2), 69-82. Erişim adresi: https:// doi.org/10.30900/kafkasegt.441228

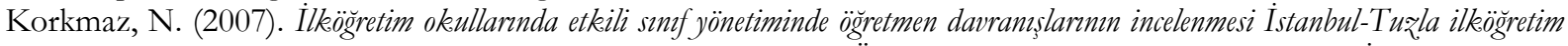
okullarnda pilot bir araştırma (Yüksek Lisans Tezi). Beykent Üniversitesi Sosyal Bilimler Enstitüsü, İstanbul.

Köleşoğlu, G. (2009). İlkögretim ögretmenlerinin liderlik özellikleri ile iletişim becerileri arasindaki ilişki (İstanbul ili Beyoğlu ilkögretim okullarnda bir uygulama) (Yüksek Lisans Tezi). Beykent Üniversitesi Sosyal Bilimler Enstitüsü, İstanbul.

Küpeli, E. (2019). Ortaokul ögretmenlerinin iletişim becerileri ile öz yeterlik algilar arasindaki ilişkinin incelenmesi (Yüksek Lisans Tezi). Kahramanmaraş Sütçü İmam Üniversitesi Sosyal Bilimler Enstitüsü, Kahramanmaraş.

LeFebvre, L. ve Allen, M. (2014). Teacher immediacy and student learning: An examination of lecture/laboratory and self-contained course sections. Journal of the Scholarship of Teaching and Learning, 14(2), 29-45. Retrieved from https://scholarworks.iu.edu/journals/index.php/josotl/article/view/4002

Lincoln, Y. S. ve Guba, E. G. (1985). Naturalistic Inquiry. Newbury Park, London, New Delhi: SAGE Publications.

Li, S., Wang, Y., Xue, J., Zhao, N., \& Zhu, T. (2020). The impact of COVID-19 epidemic declaration on psychological consequences: A study on active Weibo users. International Journal of Environmental Research and Public Health, 17(6), 1-9. Erişim adresi: https://doi.org/10.3390/ijerph17062032

Mart, M. (2014). Hemşirelikte iletişim doyumu ve örgütsel bağlılık arasindaki ilişkei (Yüksek Lisans Tezi). Haliç Üniversitesi Sağlık Bilimleri Enstitüsü, İstanbul.

Merriam, S. B. ve Tisdell, E. J. (2016). Qualitative research: A guide to design and implementation (4th Edition). San Francisco: Jossey-Bass.

Millî Eğitim Bakanlığı. (2017). Öğretmenlik mesleği genel yeterlikleri. Ankara: Öğretmen Yetiştirme ve Geliştirme Genel Müdürlüğü. Erişim adresi: http://oygm.meb.gov.tr/www/ogretmenlik-meslegi-genel-yeterlikleri/icerik/39

Nacar, F. S. (2010). Sımı ögretmenlerinin iletişim ve kişilerarası problem çöẓme becerilerinin incelenmesi (Yüksek Lisans Tezi). Çukurova Üniversitesi Sosyal Bilimler Enstitüsü, Adana.

Nacar, F. S. ve Tümkaya, S. (2011). Sınıf öğretmenlerinin iletişim ve kişilerarası problem çözme becerilerinin incelenmesi. Illkögretim Online, 10(2), 493-511. Erişim adresi: http://eds.b.ebscohost.com/eds/pdfviewer/pdfviewer?vid=0\&sid=7997c782-90ef-4b17-a75a5a7cb16aa943\%40sessionmgr103

Özdemir, E. ve Üzel, D. (2010). İlköğretim matematik öğretmen adaylarının öğretim elemanı özelliklerine yönelik görüşlerinin incelenmesi. Mehmet Akif Ersoy Üniversitesi Eğitim Fakültesi Dergisi, 10(20), 122-152. Erişim adresi: https://dergipark.org.tr/en/pub/maeuefd/issue/19393/205967

Özer, D. (2011). Etkili iletişim becerilerinin sosyal hayata uyum sağlamadaki işlevi: Furat Üniversitesi uygulaması (Yüksek Lisans Tezi). Firat Üniversitesi Sosyal Bilimler Enstitüsü, Elâzı̆̆.

Özer, N. ve Bozanoğlu, B. (2016). Öğretim elemanları tarafından sergilenen istenmeyen davranışların üniversite öğrencilerinin algılarına göre değerlendirilmesi. Kuram ve Uygulamada Eğitim Yönetimi, 22(2), 245-266. Erişim adresi: https://kuey.net/index.php/kuey/article/view/kuey.2016.010

Öztürk, İ., Akalın, S., Özgüner, İ. ve Şakiroğlu, M. (2020). Covid-19 salgınının ve karantinanın psikolojik etkileri. Turkish Studies, 15(4), 885-903. Erişim adresi: https://dx.doi.org/10.7827/TurkishStudies.44885

Patton, M. Q. (2014). Qualitative research \& evaluation methods: Integrating theory and practice. London: SAGE publications.

Samancı, O. ve Yıldırım, G. (2015). Sınıf öğretmeni adaylarına göre öğretim elemanlarının demokratik ve demokratik olmayan tutum ve davranışları. Atatürk Üniversitesi Sosyal Bilimler Enstitüsü Dergisi, 19(1), 115-128. Erişim adresi: https://dergipark.org.tr/en/pub/ataunisosbil/issue/2838/38749

She, H. C., \& Fisher, D. (2002). Teacher communication behavior and its association with students' cognitive and attitudinal outcomes in science in Taiwan. Journal of Research in Science Teaching, 39(1), 63-78. https://doi.org/10.1002/tea.10009

Şimşek, A. ve Bakır, S. (2019). Türkçe öğretmenlerinin sözel olmayan iletişim davranışlarının incelenmesi. Uluslararası Türkşe Edebiyat Kültür Eğitim Dergisi, 8(2), 1099-1118. Erişim adresi: https://dergipark.org.tr/en/pub/teke/issue/46075/580140

Taylor, M. R., Agho, K. E., Stevens, G. J. ve Raphael, B. (2008). Factors influencing psychological distress during a disease epidemic: Data from Australia's first outbreak of equine influenza. BMC Public Health, 8(1), 1-13. Erişim adresi: https://doi.org/10.1186/1471-2458-8-347 
Tepeli, K. ve Arı, R. (2011). Okul öncesi eğitim öğretmeni ve öğretmen adaylarının iletişim ve sosyal becerilerinin karşılaştırılmalı olarak incelenmesi. Selçuk Üniversitesi Sosyal Bilimler Enstitüsü Dergisi, 26, 385-394. Erişim adresi: http://dergisosyalbil.selcuk.edu.tr/susbed/article/view/177

Tomul, E. (2015). Simfta ögretmen- ögrenci iletişimi. Kıran, H. \& Çelik, K. (Eds.) içinde, Etkili sınıf yönetimi (s.146-172). Ankara: Anı Yayıncilik.

Tuna, Y. (2014). İletişim, İçinde İletişim Kavram ve İletişim Süreci (Edt: İ. Vural). Ankara: Pegem Akademi.

Uzun, T., Özdem, G. ve Kara, E. (2018). Öğretmenlerin iletişim becerileri ile öğrencilerin derse ilgileri arasındaki ilişkilerin incelenmesi. Eræ̧incan Üniversitesi Eğitim Fakültesi Dergisi, 20(3), 622-636. Erişim adresi: https://doi.org/10.17556/erziefd.376135

Yavuzer, H. (2001). Eğitim ve gelişim özellikleriyle okul çă̆ çocuğu. (7. Bask1). İstanbul: Remzi Kitabevi.

Yıldırım, A. ve Şimşek, H. (2018). Sosyal bilimlerde nitel araştırma yöntemleri [Qualitative research methods in the social sciences] (11th ed.). Ankara: Seçkin Publications.

Yılmaz, İ., Yoncalık, O. ve Çimen, Z. (2010). İletişim becerisi ile öğretimde yeterlik arasındaki ilişkinin öğrenci algılarına göre değerlendirilmesi (beden eğitimi ve spor alanı). Spormetre Beden Eğitimi ve Spor Bilimleri Dergisi, 8(4), 143-150. https://doi.org/10.1501/Sporm_0000000189

Yılmaz, N. (2011). Okul öncesi ögretmenlerinin iletişim becerileri, problem çözme becerileri ve empatik eğilim düzeyleri (Yüksek Lisans Tezi). Muğla Üniversitesi Eğitim Bilimleri Enstitüsü, Muğla.

Yolcu, H. H. (2020). Koronavirüs (covid-19) pandemi sürecinde sınıf öğretmeni adaylarının uzaktan eğitim deneyimleri. Açlö̈gretim Uygulamalar ve Araştırmalar Dergisi (AUAd), 6(4), 237-250. Erişim adresi: https://dergipark.org.tr/en/pub/auad/issue/57638/788890

Yükseköğretim Kurulu. (2018). Öğretmen yetiştirme lisans programlar. Ankara Üniversitesi Basımevi Müdürlüğü, Ankara. Erişim adresi: https://www.yok.gov.tr/kurumsal/idari-birimler/egitim-ogretim-dairesi/yeni-ogretmenyetistirme-lisans-programlari

Yüksel, İ. (2005). İletişimin iş tatmini üzerindeki etkileri: Bir işletmede yapılan görgül çalışma. Doğus Üniversitesi Dergisi, 6(2), 291-306. Erişim adresi: http://journal.dogus.edu.tr/index.php/duj/article/view/136/152

Zlatic, L., Bjekic, D., Marinkovic, S. ve Bojovic M. (2014). Development of teacher communication competence. Journal of Social and Behavioral Sciences, 116, 606-610. https://doi.org/10.1016/j.sbspro.2014.01.265

\section{EXTENDED ABSTRACT}

Communication is basically understanding, assimilating and reacting to other people (Özer, 2011, p. 20). Communication skill refers to being sensitive to verbal and non-verbal messages, listening effectively and reacting to them (Erözkan, 2007, p. 60). The effectiveness of communication skills can be facilitative in human and professional relationships (Akgün \& Çetin, 2018, p. 104). The importance of communication increases even more in professions that require intensive communication with people. Teaching is one of such professions and effective use of communication skills of teachers in educational processes can affect the quality of education, student achievement and interest (Uzun, Özdem, \& Kara, 2018, p. 625). Because the learning process is also a communication and interaction process (Baykara Pehlivan, 2005, p. 17).

Studies conducted during in-service periods to improve the communication skills of teachers are mostly seminars, courses, etc. continues with educational activities. In the pre-service period, "Human Relations and Communication" course is included within the scope of general culture elective courses in the teaching undergraduate programs in order to train teacher candidates as teachers who can communicate effectively (Council of Higher Education, 2018, p. 19). In addition, it is also important that instructors are role models in providing effective communication skills to teacher candidates. Like all students, teacher candidates follow the language use, pronunciation and oratory skills, gestures, facial expressions and all body language usage styles of their teachers. The behaviors they experience by watching and listening to their teachers shape their behavior in communication processes. For this reason, it is thought that it may be effective for teachers to experience communication experiences that will set an example for their students at all levels from preschool to higher education. Especially, the communication skills of teaching staff who work in education faculties that are teacher training institutions, are considered important for teacher candidates who will train future generations to become teachers who can communicate effectively. It is seen that there are various studies in the literature that examine the communication skills of teachers (Aslan Bağc1 \& Efilti, 2019; Baydar Posluoğlu, 2014; Bozkurt Bulut, 2004; Derici Cevap, 2017; Durukan \& Maden, 2010; Kadığlu Ateş \& Bulut, 2019; Kayhan, 2014; Kılıç, 2013; Küpeli, 2019; Nacar \& Tümkaya, 2011; Şimşek \& Bakır, 2019; Uzun, Özdem \& Kara, 2018; Yılmaz, 2011). However, it can be said depending on the lack of studies examining the communication skills of teaching staff especially about those working in teacher training institutions, is effective in the emergence of this study. From this point of view, the aim of the study is to evaluate the communication skills of academic staff working in the education faculty from the perspective of teacher candidates. 
In direction with this purpose, the research mainly searches answers to the following questions:

1. What are the experiences of the teacher candidates regarding the communication skills of teaching staff?

2. What are the expectations of teacher candidates from instructors regarding communication?

The research was designed according to the basic qualitative research design. The teacher candidates that are educating in thirteen different branches in the faculty of education at a state university in Turkey during spring semester of 2019-2020 academic year, form the participants of research. In determining the participants which are 61 women and 17 men, two-stage sampling method was used. Accordingly, criterion sampling was used in the first stage and maximum diversity sampling was used in the second stage. In the study, an open-ended questionnaire form was used as a data collection tool. The obtained data were analyzed by content analysis.

According to the results obtained from the study, teacher candidates evaluated the communication skills of the teaching staff negatively. According to the research results, the most negatively evaluated communication skills of the teaching staff; are empathy, effective listening, understanding/tolerant behavior, using self-esteem development language and being open to criticism. Therefore, the teacher candidates emphasize that the lecturers from whom they take courses as people that cannot empathize, are not understanding and tolerant, do not listen effectively, do not have strong rhetoric skills, are prejudiced, do not approach all students equally and are not open to criticism. On the other hand, the most positively evaluated communication skills are choosing the appropriate clothing and using the Turkish correctly. According to these evaluations of the teacher candidates, the instructors are generally careful about the dressing process in the communication process and they use Turkish effectively. It is also understood that they generally communicate with respect and attach importance to eye contact.

According to the results obtained in the second dimension of the study, teacher candidates expect from their instructors to show empathy, understanding and tolerance, listen to their students effectively, be respectful by using oratory and body language effectively and use a language that is free of prejudice, plain, clear, understandable and self-esteem. When considered together with the results obtained from the first dimension of the study, it can be said that these results become more meaningful. As a matter of fact, although the teacher candidates express their deficiencies regarding the communication skills of the teaching staff, they expect to eliminate these deficiencies.

As a result, in this study, it was determined that the instructors are generally evaluated positively about the choice of dress and the correct use of Turkish in the communication process; whereas they were evaluated relatively negative in terms of empathy, active listening, understanding / tolerant behavior, using self-esteem enhancing language and being open to criticism. Therefore, from the perspective of teacher candidates, it can be said that although the lecturers who attend their classes have some strong communication skills, they are weak and have more communication skills they need to develop. 